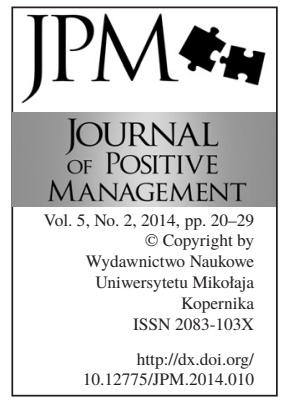

\section{MUTUAL MENTORING AS A TOOL FOR MANAGING EMPLOYEES OF DIFFERENT GENERATIONS IN THE ENTERPRISE}

\author{
Matgorzata Baran
}

Collegium Civitas, Warszawa, Poland, e-mail: malgorzata.baran@collegium.edu.pl

\begin{abstract}
Purpose: The aim of this paper is to characterize mutual mentoring as a tool of intergenerational staff management in the enterprise and to examine the effects of the mutual mentoring in Polish enterprises.

Methodology: The research was conducted using a survey on a sample of 250 business representatives from all over Poland. The subjects were mainly CEOs or members of the management staff. The criteria for selection of enterprises for this study were: enterprise size (small, medium, large companies), the age structure of the staff. The aim of the study was to identify the process of mutual mentoring in enterprises - whether it is present and what results or benefits it brings to enterprises and their employees.
\end{abstract}

Findings: Almost $40 \%$ of the surveyed employers confirm that in their firms knowledge is transferred between employees: this occurs through teaching junior employees by the senior and more experienced ones and there also occur inverse relations, i.e., junior employees share their knowledge with the senior ones. This leads to formation of the added value both for the employees and the whole business. Employers observe numerous benefits from the implementation of mutual mentoring in their organisations. The main ones include: the acquisition and development of competences and skills by employees, the improvement of work environment conducive to involvement of employees in work and the increase of team motivation.

Implications: In the Polish literature on the subject the aspect of mutual mentoring in companies has not yet been discussed. The conclusions of the presented analysis provide a basis for larger and more detailed research and the development of practical recommendations for business managers.

Originality/value: The author has presented a unique theory of mutual mentoring as a tool of intergenerational staff management in the enterprise. Mutual mentoring defined as modified version of traditional mentoring and involves the assumption that different generations of employees become each other's mentors or teachers, thus ensuring mutual substantive and organisational support in the workplace as well as natural transfer of knowledge and experience within the organisation. Author presented original research results: effects of the mutual mentoring in Polish enterprises.

Key words: mutual mentoring, mentoring in the enterprise, staff management

Paper type: Research paper 


\section{Introduction}

Significant changes in the labour market are due to the progressive ageing of the population and the reduction of the number of employees. On the one hand, employers are forced to manage the (quantitatively) limited labour force resources, on the other hand they have to manage employees who are older than they used to be. This gives rise to a risk of a generation gap which in turn stimulates the dissonance between "experience not keeping up pace with knowledge" and "new knowledge without any experience." This requires that entrepreneurs use a new approach to business management which would include particular emphasis on inter-generational employee management, i.e. an approach to the management of employees representing different generations. This should allow to utilise human resources in the enterprise in an efficient and rational way while maintaining resources of knowledge and skills at the appropriate level. In the face of changes in the labour market essential for employers are solutions that enable to retain in the enterprise employees aged 50+, while making maximum use of the capabilities of this group.

The aim of this paper is to characterize mutual mentoring as a tool of intergenerational staff management in the enterprise and to examine the effects of the mutual mentoring in Polish enterprises.

\section{The Changing Labour Market in Poland and in the European Union}

For several years the diminishing number of employees in the productive age has been perceived in the European Union as a threat to the labour market. The dynamics of the population in the productive age in the EU-27 shows that the group of employees aged 55-64 will increase by $16 \%$ by 2030 , while other groups show a downward trend - by 5\% for employees aged $40-54$ years and by $15 \%$ for employees aged 25-39 (Ilmarinen, 2012). This marked demographic change is due to the increased life expectancy and a fall in fertility rates. As a result, Europe's workforce will become older than ever (OECD, 2010).

In the next 10-15 years, employers in Poland will have to deal with a clear, sharp fall in the labour supply in the domestic market. According to the forecasts by the Polish Central Statistical Office (GUS) for 2010-2035 the population in the productive age in Poland will decline by over four million people, of which the largest drop will occur in the coming years. As a result, in the years 2020-2025 the group of employees aged 24-26 will be reduced by almost one third, while the group of employees aged 25-34 by one fifth (GUS, 2009).

It is estimated that at the end of 2012 the population in the productive age accounted for over 6.8 million people, while its share in the total population was $17.8 \%$ (in 2000 it accounted for 5.7 million and almost $15 \%$ and in 1990 less than $13 \%$ respectively). Compared to 2011, the number of people in post-productive age grew by more than 200 thousand (GUS, 2013). However, in 2035 the number 
MUTUAL MENTORING AS A TOOL

Małgorzata Baran of people in the post-productive age will reach about 9.6 million, i.e. it will rise to $26.7 \%$ (GUS, 2010).

According to the GUS research and analyses, for every 100 people in the productive age there are currently 29 people in the pre- and post-productive age, while in 2000 it was 40 and 24 respectively, and in $1990-50$ and 22 (GUS, 2013). Low fertility rates accompanied by the phenomenon of lengthening of the average life span will increase the process of reduction of the pool of labour force in the labour market and growth of the proportion of senior employees.

\section{Mutual Mentoring as a tool for intergenerational staff management}

\subsection{Fundamentals of mutual mentoring}

One of the solutions to retain older people in the labour market is the application of an age management strategy. However, the idea of age management in the organisation is relatively little known among Polish employers. Nor is there a clear definition of the term "age management" (Litwiński, Sztanderska, 2010). However, it can be assumed that from the employers' perspective age management can be defined as developing and implementing tools and methods of operation within enterprises and institutions that will allow them to use rationally their human resources, including older employees. The characteristic of age management is the approach geared to address the specific (age-related) constraints and needs of employees that will optimise the efficiency of employees of all age groups in the enterprise (TEAN, 2007).

The possibility to implement the age management concept exists in every enterprise, however, crucial here are rules of conduct which do not discriminate against senior employees but use their potential to the benefit of both parties - the employers and the employees (Strom, Strom, 2011). One of the tools to achieve efficient managing of employees of different ages is mutual mentoring. It is a modified version of traditional mentoring (Clutterbuck, 2004), i.e. introducing new employees to the organisation by employees who are senior in terms of the length of service or age (Karwala, 2009; Ragins, 2011). Mutual mentoring involves the assumption that different generations of employees become each other's mentors or teachers, thus ensuring mutual substantive and organisational support in the workplace as well as natural transfer of knowledge and experience in a given organisation.

Mutual mentoring is a relationship in which a mentee (employee under the care of the a mentor) may ask his/her mentor for guidance or for working out a solution to some problem together in a situation when he/she needs advice or support. A mentor may take one of two roles in the enterprise, either as an organisational care-keeper (organisational mentor) or as a technology care-keeper (technology mentor). An organisational mentor is most often a senior employee 
with extensive life and professional life experience, a person with authority in the organisation and who introduces employees of younger age and shorter length of service (as age, experience and length of service are most often interdependent) in the secrets of functioning of the enterprise. A technology mentor is usually

a person of young age, well acquainted with new technologies (Hi-Tech), who is capable to use modern equipment, tools and software. A technology mentor is of extensive support to more senior employees in the enterprise.

\subsection{Application of mutual mentoring in the enterprise}

Goals of mutual mentoring in the enterprise may be the following:

- transfer of knowledge and experience among employees, including the so-called tacit knowledge,

- practical training of new employees and adaptation to a new job,

- keeping the most valuable employees with the firm,

- building relations with new persons in the enterprise,

- carrying out a new, difficult project,

- personal development of participants of the mutual mentoring process.

The execution of the mutual mentoring process consists of 4 phases (identification, planning, implementation, and completion). The characteristics of each of the phases are presented below:

1) The identification phase:

- identification of potential mentors in the enterprise (the criteria include: age, experience, IT knowledge, at least "good" professional competence, determination whether an employee wants to be a mentor, determination whether an employee has the characteristics of a "good teacher" - the so-called mentoring skills: active listening, clear communication, knowledge sharing, willingness to learn and develop professionally, authority),

- checking on needs (problems) of employees in the enterprise and on their development goals.

2) The planning phase:

- Determination of employee pairs for the mutual mentoring process,

- Determination of the subject of mutual mentoring,

- Setting the time limit for mutual mentoring activities,

- Determination of the purpose of mutual mentoring activities,

- Determination of the expected results.

3) The implementation phase:

- Regular meetings of the master and the student,

- Meetings of intervention,

- Quiet support for each other,

- The employer's monitoring of the mutual mentoring process. 
MUTUAL MENTORING AS A TOOL

Małgorzata Baran
4) The completion phase:

- Ending the mutual mentoring relationship - in most cases mutual mentoring programmes have a specific time frame.

In mutual mentoring the most important factor is the co-operation of three different groups of employees (senior and junior employees and the management staff), because thanks to it the enterprise is internally consistent and thus more efficient.

Factors for success of the mutual mentoring process in the enterprise include:

- trust of employees,

- openness of employees,

- initiative and support of the employer,

- compatibility of the master and the student,

- understanding of the goals set,

- giving feedback, willingness to share knowledge,

- - co-responsibility of the master for success or failure of the student.

Mutual mentoring brings a number of benefits which include: sharing knowledge and experience among employees in the enterprise, developing their skills, improvement of inter-generational relations, willingness to implement changes in the organization. Both groups of employees get to know each other's ways of thinking, recognise errors in mutual perception, work out methods of mutual co-operation as well as balance their skills.

\section{Mutual mentoring in Polish Enterprises - empirical research}

In order to determine whether mutual mentoring is present in Polish enterprises, research* was conducted in enterprises which employ at least 10 employees (small, medium and large companies), operating in different voivodeships, in various industries and with human resources representing different generations.

Vast majority of respondents say that in their enterprises knowledge is most usually transferred through direct consultations (70\%) and through internal trainings taking place in the office $(66 \%)$. More than half of the enterprises surveyed use tools in the form of printed materials (57\%), internal databases and intranet (45\%). In turn, $39 \%$ of respondents point at the role of mentors in the process of knowledge sharing in the enterprise, i.e. in almost every third enterprise mutual mentoring is applied. A group of $35 \%$ of the surveyed enterprises confirm that in their enterprises employees make use of an organisational mentor's

* The author and the research team conducted a survey on a sample of 250 business representatives from all over Poland. The subjects were mainly CEOs or members of the management staff. The criteria for selection of enterprises for this study were: enterprise size, the age structure of the staff. The aim of the study was to identify the process of mutual mentoring in enterprises - whether it is present and what results or benefits it brings to enterprises and their employees. 
help, while in $22 \%$ of the surveyed enterprises there are employees who act as technology mentors. Table 1 illustrates how knowledge-sharing tools are most often used in enterprises.

\begin{tabular}{lc}
\hline Tools for transfer of knowledge in the enterprise & \\
\hline Face-to-face consultations with colleagues & $70 \%$ \\
\hline Direct trainings (in the office) & $66.4 \%$ \\
\hline Printed documents, such as educational materials / procedures / descriptions of activities & $57.3 \%$ \\
\hline Transfer of information via intranet or Internet databases & $45.5 \%$ \\
\hline Aid of the organisational mentor & $34.5 \%$ \\
\hline Training through an e-learning platform & $29 \%$ \\
\hline Aid of the technology mentor & $22 \%$ \\
\hline Other & $2.7 \%$ \\
\hline
\end{tabular}

MUTUAL MENTORING AS A TOOL

Małgorzata Baran

Table 1.

Tools for transfer of knowledge in the enterprise

The employers surveyed perceive their role in the enterprise mutual mentoring process in a variety of ways, as shown in Figure 1. More than half of respondents (53\%) see a need to support the whole process, starting from the employee requirements determination phase, planning and implementation of mutual mentoring. On the other hand, $31 \%$ of employers believe that it is sufficient to allocate specific funds for mutual mentoring to be effectively implemented in the enterprise. In the opinion of $16 \%$ subjects mutual mentoring in the enterprise does not require involvement of the employer.

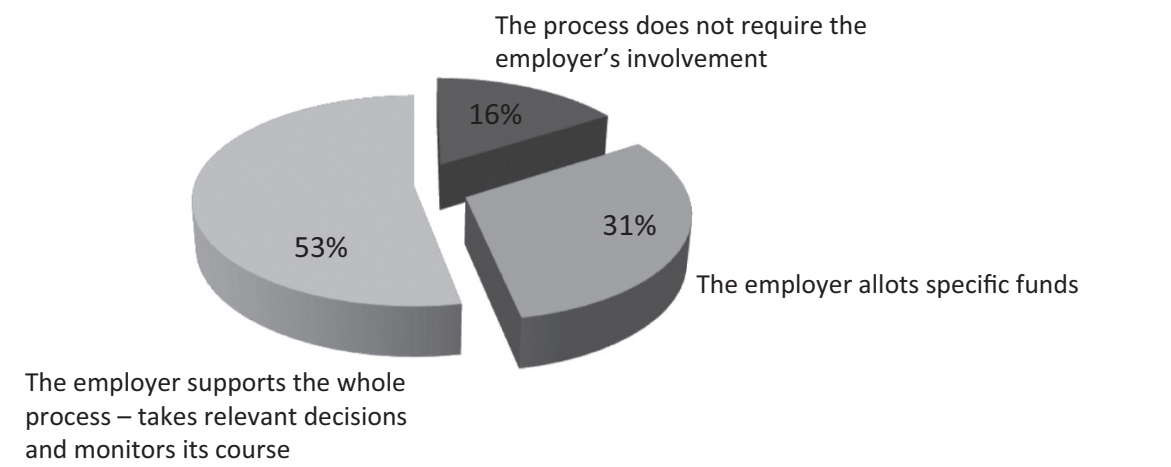

Of the 250 enterprises surveyed, almost 100 apply mutual mentoring as an employee management tool in respect of employees of different generations. Respondents observe a number of effects of mutual mentoring in their organisations (research findings in this area are illustrated in Figure 2).

For the vast majority of employers the benefit from implementation of mutual mentoring in the enterprise is in the acquisition of new qualifications and skills by

Figure 1. Role of the employer in mutual mentoring 
MUTUAL MENTORING AS A TOOL

Małgorzata Baran

Figure 2.

Results of application of mutual mentoring in the surveyed enterprises employees (81\%), as well as developing their existing skills and qualifications $(74 \%)$. More than half of the respondents indicated the enrichment of experience (57\%), improvement of work environment conducive to greater involvement in work $(55 \%)$ and increased motivation for work (53\%) as further effects of mutual mentoring in the enterprise. A significant share of the respondents' responses concerned the following benefits of mutual mentoring: better employees' preparedness for challenges at work (44\%), identification of the employees' competences which need to be developed (43\%), mentored employees becoming familiar with their strengths and weaknesses in the enterprise at a given position ( $42 \%$ ), broader knowledge of the organisation $(41 \%)$, better use of the opportunities and possibilities inherent in the environment of the organisation (40\%). Additionally, every third respondent indicated the expansion of contact

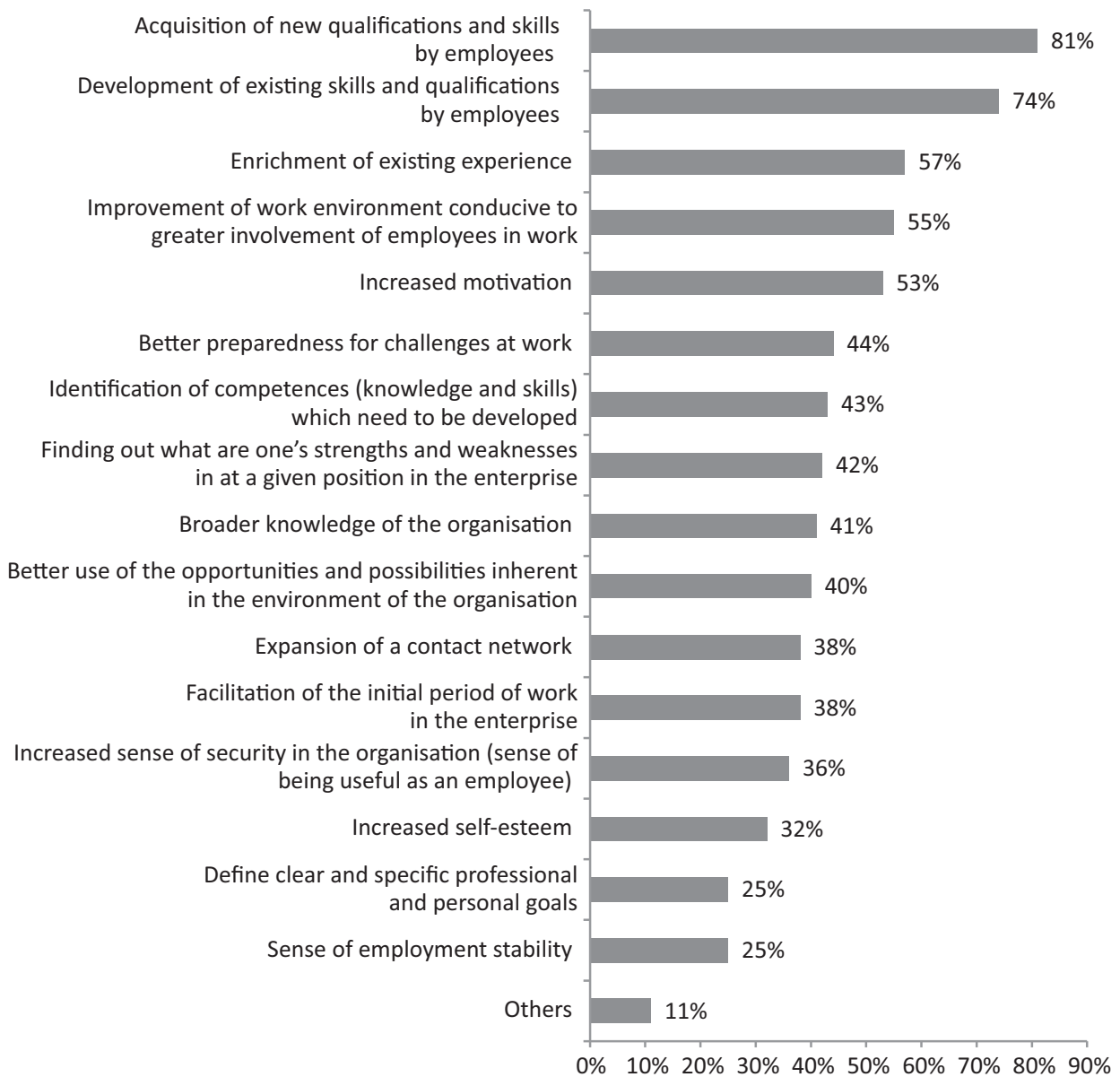


networks (38\%), facilitation of the initial period of work at the enterprise (38\%), an increased sense of security - the sense of being useful as an employee (36\%), and increased employee self-esteem (32\%) as a result of mutual mentoring in an organisation.

In $39 \%$ of the surveyed companies there is a transfer of knowledge and skills between employees - teaching younger by the older and more experienced workers. As the results demonstrate, in some firms simultaneously the inverse process can be observed - younger employees bring in their knowledge of technological novelties and their IT skills. They pass on their skills and knowledge in the course of work to older employees. Each of the employers participating in the study emphasized the key role of mentors in the functioning of the mutual mentoring process. Table 2 shows the most important functions of an organisational mentor.

\begin{tabular}{ll}
\hline Key functions of an organisational mentor & \\
\hline Counselling and sharing contacts & $42 \%$ \\
\hline Support to overcome barriers to communication within the team & $37 \%$ \\
\hline Help in avoiding mistakes & $35 \%$ \\
\hline Inspiring to action & $32 \%$ \\
\hline Help in understanding the organisation & $30 \%$ \\
\hline Creating the right work environment & $27 \%$ \\
\hline Intellectual stimulation & $24 \%$ \\
\hline Help in identifying the strengths and weaknesses of the employee & $23 \%$ \\
\hline Assisting in the development of personal competences & $23 \%$ \\
\hline Motivating and developing internal motivation & $22 \%$ \\
\hline Spreading enthusiasm and innovativeness & $14 \%$ \\
\hline Transfer of know-how (IT, high-tech) & $12 \%$ \\
\hline The evaluation combined with extensive feedback & $8 \%$ \\
\hline Other & $1 \%$ \\
\hline
\end{tabular}

Table 2. Key functions of an organisational mentor

Table 3 presents the most important functions of the technology mentor in the enterprise (as indicated by respondents).

According to respondents, the key task of the organisational mentor consists in counselling and sharing contacts ( $42 \%$ of responses), support in overcoming barriers (37\%), help in avoiding errors through sharing experience $(35 \%)$, inspiring new employees to work (32\%) and making junior employees (in terms of length of service) familiar with the functioning of the enterprise $(30 \%)$. On the other hand, the most important role of a technology mentor in the enterprise is to share IT knowledge (69\% of responses). A technology 
MUTUAL MENTORING AS A TOOL

Małgorzata Baran

Table 3.

Key functions of a technology mentor

\begin{tabular}{ll}
\hline Key functions of a technology mentor & \\
\hline Transfer of know-how (IT, high-tech) & $69 \%$ \\
\hline Spreading enthusiasm and innovativeness & $45 \%$ \\
\hline Help in avoiding mistakes & $35 \%$ \\
\hline Inspiring to action & $32 \%$ \\
\hline The evaluation combined with extensive feedback & $30 \%$ \\
\hline Intellectual stimulation & $25 \%$ \\
\hline Counselling and sharing contacts & $15 \%$ \\
\hline Support to overcome barriers to communication within the team & $15 \%$ \\
\hline Creating the right work environment & $15 \%$ \\
\hline Help in identifying the strengths and weaknesses of the employee & $14 \%$ \\
\hline Motivating and developing internal motivation & $11 \%$ \\
\hline Assisting in the development of personal competences & $10 \%$ \\
\hline Help in becoming familiar with the organisation & $8 \%$ \\
\hline Other & $1 \%$ \\
\hline
\end{tabular}

mentor usually spreads enthusiasm and innovativeness (45\%), by teaching others he/she helps them avoid mistakes (35\%), as well as inspires others to take action (32\%).

\section{Conclusion}

The results of the conducted studies confirm that mutual mentoring used consciously in the enterprise is a tool for managing employees of different generations. Although the term "mutual mentoring" is not commonly known among entrepreneurs, one third of employers acknowledge that in their enterprises the transfer of knowledge and skills among staff does take place. This occurs both through teaching the younger by the older and more experienced staff, and also through inverse relations, i.e. younger employees sharing their knowledge with older employees. Employers observe numerous benefits from the implementation of mutual mentoring in their organisations. The main ones include: the acquisition and development of competences and skills by employees, the improvement of work environment conducive to involvement in work and the increase of team motivation. Employers perceive their role in the mutual mentoring process as one of support or supervision. As a result of employee involvement in mutual mentoring and support from the employer there is an effective transfer of knowledge and experience between employees of different generations. They become mentors for each other, and this leads to added value for both the employees and the whole enterprise. 
References

Clutterbuck D. (2004), "Everyone Needs a Mentor. Fostering talent in your organisation”, fourth edition, London CIPD.

Ilmarinen J. (2012), "Wspieranie aktywnego starzenia się w miejscu pracy, European Agency for Safety and Health at work", https://osha.europa.eu/pl/publications/arti cles/promoting-active-ageing-in-the-workplace (accessed 20 August 2013), pp. 1-8.

GUS (2013), "Podstawowe informacje o rozwoju demograficznym Polski do 2012 roku", Raport GUS, www.stat.gov.pl/gus (accessed 15 October 2013).

GUS (2009), "Prognoza ludności na lata 2008-2035”, Raport GUS, www.stat.gov.pl/gus (accessed 15 October 2013).

Karwala S. (2009), "Mentoring jako strategia wspierająca wszechstronny rozwój osobisty”, Wyższa Szkoła Biznesu-National Luis University, Nowy Sącz.

Litwiński J., Sztanderska U. (2010), "Zarządzanie wiekiem w przedsiębiorstwie”, PARP, Warszawa.

OECD (2010), "Work-force ageing in OECD countries", Employment Outlook, Report OECD.

Ragins B.R. (2011), "Relational Mentoring: A Positive Approach to Mentoring at Work", The Oxford Handbook of Positive Organizational Scholarship, Oxford Handbooks Online http://www.oxfordhandbooks.com.pl (accessed 19 October 2013).

Strom P., Strom R. (2011), "A Paradigm for Intergenerational Learning”, The Oxford Handbook of Lifelong Learning, Oxford Handbooks Online http://www.oxfordhand books.com.pl (accessed 21 October 2013).

TAEN - The Age and Employment Network (2007), "Managing the Ageing Workforce: an introductory guide to age management for HR professionals".
MUTUAL MENTORING AS A TOOL

Małgorzata Baran 